\title{
Development of fragility curve based on incremental dynamic analysis curve using ground motion Aceh earthquake
}

\author{
$Z u \operatorname{Irfan}^{1 *}$, Abdullah ${ }^{2}$, and Moch. Afifuddin ${ }^{2}$ \\ ${ }^{1} \mathrm{PhD}$ Candidate, Doctor of Engineering Study Program, Syiah Kuala University, J1. Syech Abdurrauf, Banda Aceh, 23111, Indonesia \\ ${ }^{2}$ Civil Engineering Department, Syiah Kuala University, Jl. Syech Abdurrauf, Banda Aceh, 23111, Indonesia
}

\begin{abstract}
History records that Aceh has been hit by earthquakes several times, including the largest recorded, on December 26, 2004 with a magnitude of 9.3 SR. In connection with the history of disasters that have occurred, there is a need for safety and disaster preparedness. It is very important to conduct a feasibility study of the existing public buildings used in disaster preparedness for vulnerability against earthquakes. The type of building damage caused can predicted by referring to the fragility curve. This research conducted on evaluating the seismic performance of existing buildings in Banda Aceh City by developing a fragility curve based on Incremental Dynamic Analysis (IDA). The existing buildings that are the main focus of this study include the Tsunami Vertical Evacuation (TVE) of Lambung, TVE Alu Deah Teungoh, TVE TDMRC, SDN 48 Banda Aceh, SMPN 11 Banda Aceh, Baiturrahim Ulee Lheu Mosque, and the Subulussalam Punge Mosque. The IDA method is applied to predict and estimate the performance of the structure using several ground motions. The resulting set of IDA curves were further analyzed to form the fragility curve. The fragility curve becomes the basis for assessing the seismic performance of building structures rationally.
\end{abstract}

\section{Introduction}

Aceh province is located on a megathrust and ring of fire, with the potential for a large earthquake to occur. History records that several large earthquakes have occurred in Aceh. However, in 2004 an earthquake measuring 9.3 on the Richter Scale devastated the city of Banda Aceh which was followed by a tsunami. In connection with the history of disasters that have occurred, there is a need for safety and disaster preparedness, especially in dealing with building damage. Feasibility studies of existing buildings against earthquakes are very important to do because existing buildings are buildings used in disaster preparedness. The type of building damage caused by the earthquake can be seen and predicted by referring to the fragility curve. The fragility curve is a curve that shows how big the probability of the building's vulnerability when exposed to an earthquake [1].

Research related to the fragility curve has been carried out by Irvansyah [2] who studied the fragility curve of school buildings using the IDA method and Aulia [3] with the pushover method. Therefore, it is very important to be developed the fragility curve considering that Banda Aceh City is prone to disasters, especially earthquakes. The fragility curve will show the probability of damage to the building structure with various discrete damage conditions based on Hazus [4], namely light damage, moderate damage, extensive damage, and complete damage. Based on the above hypothesis, a research will be conducted on evaluating the seismic performance of the existing buildings in Banda Aceh City by developing a fragility curve based on incremental dynamic analysis. The method of Incremental Dynamic Analysis (IDA) is applied to predict and estimate the performance of the structure using several ground motions. The resulting set of IDA curves were further analyzed to form the fragility curve of the building structure. The fragility curve becomes the basis for assessing the seismic performance of building structures rationally.

\section{Data and method}

\subsection{Research object}

This study only focuses on assessing the condition of the existing building which is carried out by survey or direct assessment. Existing buildings are buildings that are in the utilization stage. This study examines existing buildings scattered in Meuraxa District, Banda Aceh City. The distribution of these buildings can be seen in Figure 1 as follows:

* Corresponding author: zuirfan.eng@gmail.com 


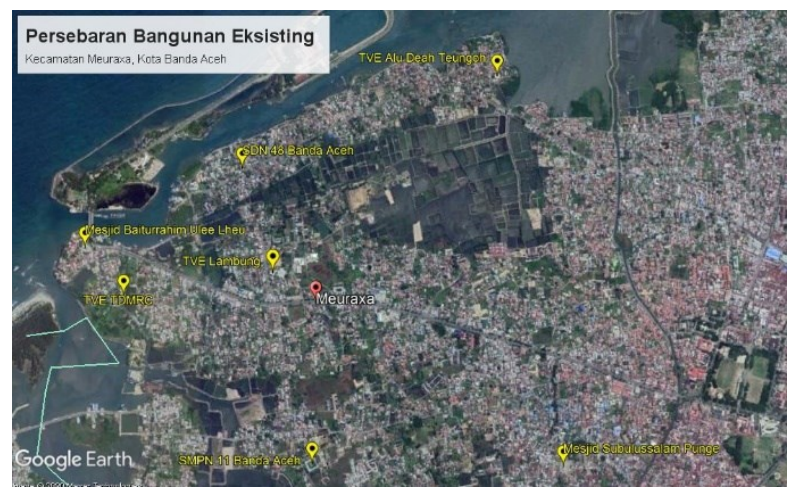

Fig 1. Map of the distribution of existing buildings that are the object of research

Existing buildings that are the object of research in this study include the Tsunami Vertical Evacuation (TVE) of Lambung, TVE Alu Deah Teungoh, TVE TDMRC, SDN 48 Banda Aceh, SMPN 11 Banda Aceh, Baiturrahim Ulee Lheu Mosque, and the Subulussalam Punge Mosque. Existing buildings that are the object of research can be seen in Figure 2 to 8 .

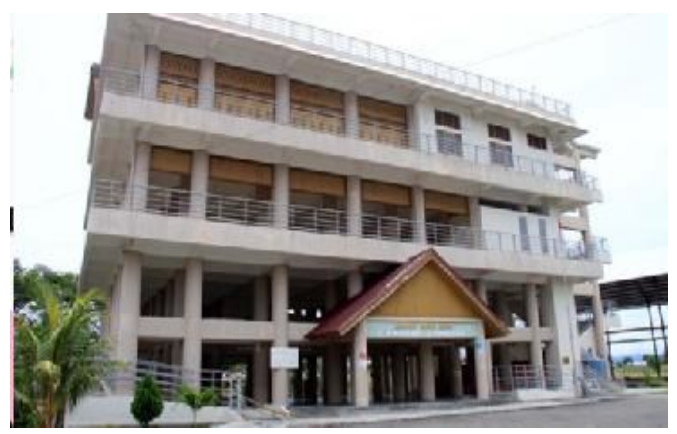

Fig 2. TVE Lambung

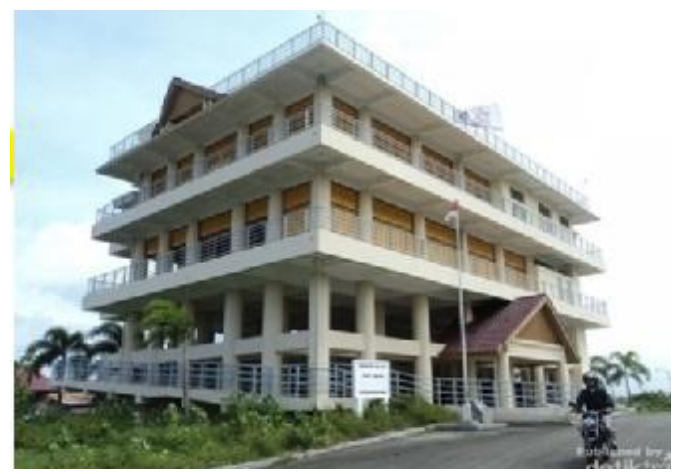

Fig 3. TVE Alu Deah Teungoh

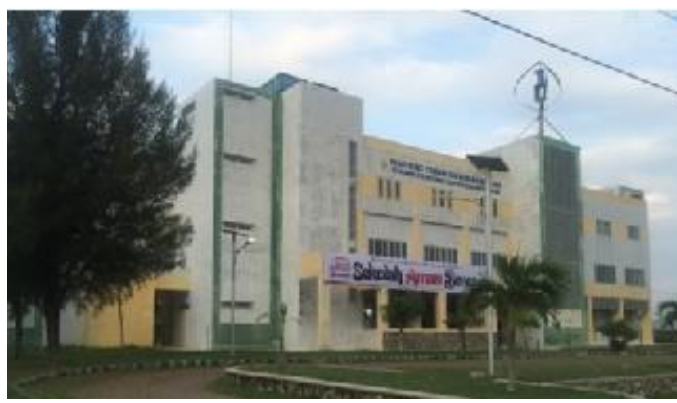

Fig 4. TVE TDMRC

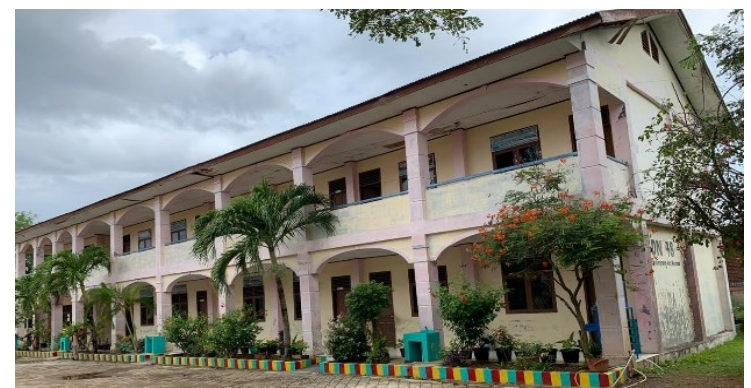

Fig 5. SDN 48 Banda Aceh

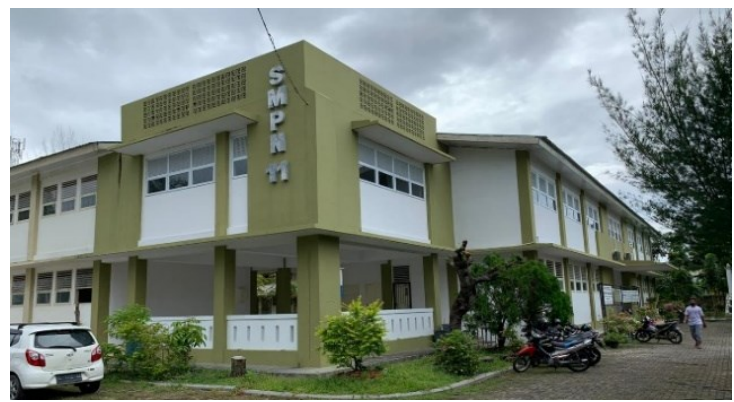

Fig 6. SMPN 11 Banda Aceh

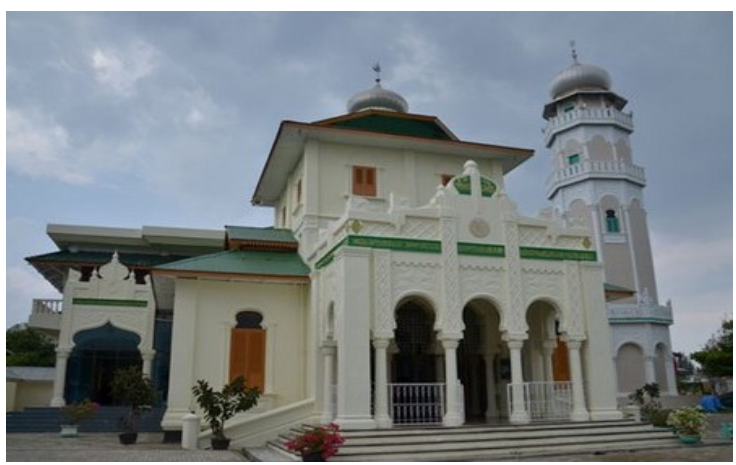

Fig 7. Baiturrahim Ulee Lheu Mosque

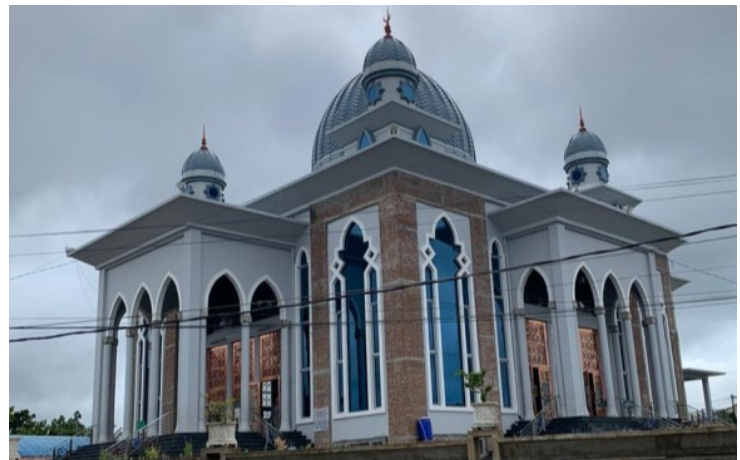

Fig 8. Subulussalam Punge Mosque

\subsection{Ground motion records}

Ground motion records taken are earthquakes that have occurred and caused severe damage to building structures. In addition to earthquake data from the Aceh area, this study also used several records of earthquake data that had occurred outside the Aceh area. The ground motion records used is the earthquake that causes significant damage and losses. The more earthquake data used, the more the characteristics of the structure will be shown. In this study, 22 earthquake records will be used which can be seen in Table 1 . 
Table 1. List of Ground Motion Records used.

\begin{tabular}{|l|c|}
\hline \multicolumn{1}{|c|}{ Gempa } & Magnitude \\
\hline Chi-Chi (Taiwan) & 7,3 \\
\hline Friuli (Italia) & 6,5 \\
\hline Hollister (USA) & 5,6 \\
\hline Imperial Valley (USA) & 6,5 \\
\hline Kobe (Japan) & 6,9 \\
\hline Kocaeli (Turkey) & 7,4 \\
\hline Landers (USA) & 7,3 \\
\hline Loma Prieta (USA) & 6,9 \\
\hline Northridge (USA) & 6,7 \\
\hline Trinidad (USA) & 6,7 \\
\hline Andaman-East 2004 & 9,3 \\
\hline Andaman-North 2004 & 9,3 \\
\hline Simeulu 1-East 2012 & 8,5 \\
\hline Simeulu 1-North 2012 & 8,5 \\
\hline Simeulu 2-East 2012 & 8,1 \\
\hline Simeulu 2-North 2012 & 8,1 \\
\hline Bener Meriah-East 2013 & 6,1 \\
\hline Bener Meriah-North 2013 & 6,1 \\
\hline Pidie Jaya-East 2016 & 6,5 \\
\hline Pidie Jaya-North 2016 & 6,5 \\
\hline Banda Aceh-East 2020 & 5,5 \\
\hline Banda Aceh-North 2020 & 5,5 \\
\hline
\end{tabular}

Source: www.peer.berkeley.edu [5] dan BMKG [6]

\subsection{Modelling structure}

Structural modeling was carried out on 7 existing buildings in Ulee Lheue. The structural system that will be modeled into SAP2000 is in the form of a space frame. SAP2000 is software from Computer and Structures, Inc. SAP 2000 has an integrated system to model, analyze, design and optimize a structure. Loads that are inputted in the SAP2000 program are loads that are reviewed in structural planning in the form of dead loads, live loads and earthquake loads. To obtain the ultimate load from the loads that may occur on the structure, a combination of factored loads is carried out that follows the rules in SNI 1726-2019 [7]. The results of the modeling of the building structure can be seen in Figure 9 to 15.

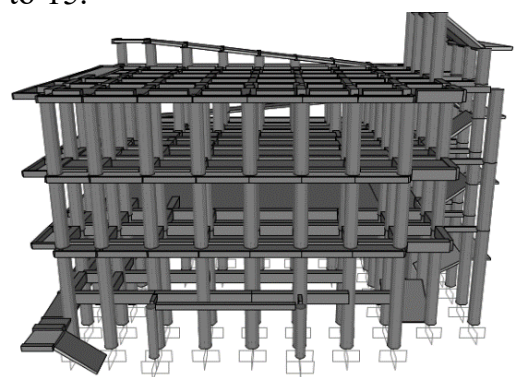

Fig 9. 3D Model of TVE Lambung

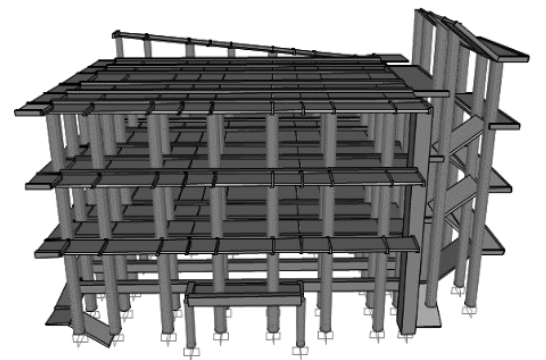

Fig 10. 3D Model of TVE Alu Deah Teungoh

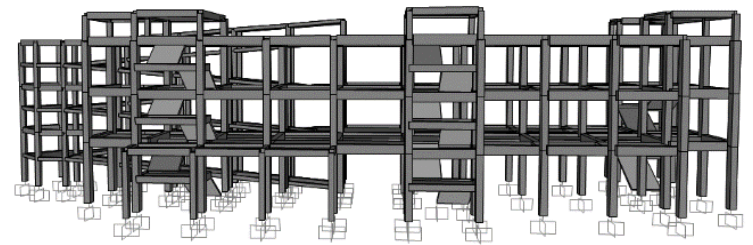

Fig 11. 3D Model of TVE TDMRC

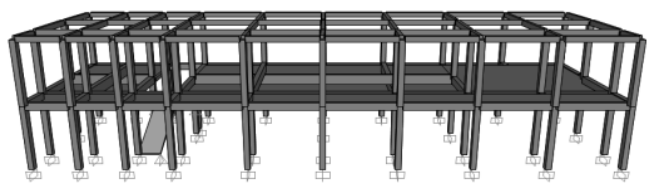

Fig 12. 3D Model of SDN 48 Banda Aceh

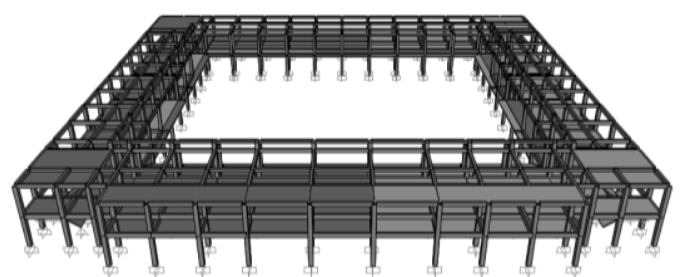

Fig 13. 3D Model of SMPN 11 Banda Aceh

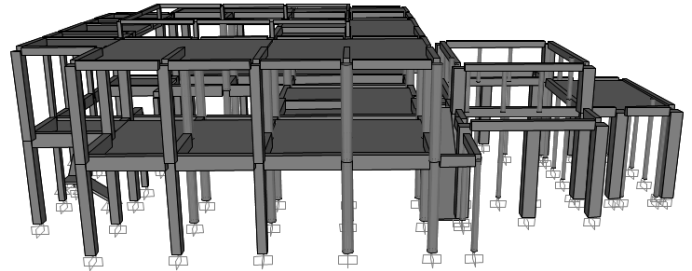

Fig 14. 3D Model of Baiturrahim Ulee Lheu Mosque

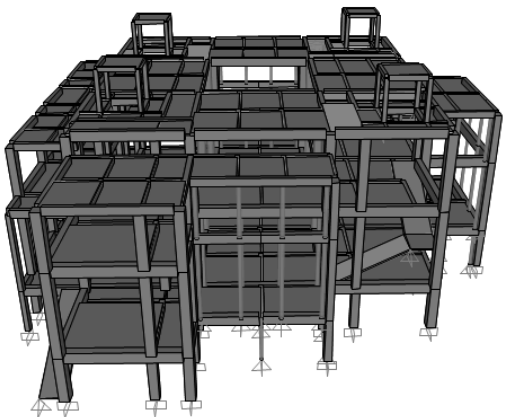

Fig 15. 3D Model of Subulussalam Punge Mosque 


\subsection{Incremental dynamic analysis}

According to Tiwari and Kasnale [8], incremental dynamic analysis (IDA) is an analysis to study the whole earthquake with different intensities, which is applied to the model of the building structure until it collapses. IDA is done by performing a non-linear time history analysis. In non-linear time history analysis, the structural model is subjected to one or more earthquake records (accelerogram) which is multiplied by a scale factor (scalar multiplication) for various levels of earthquake intensity that are expected to occur. 'force' the structure to work over the entire range of behaviour; from the elastic phase to the plastic phase (inelastic) until it finally reaches global dynamic instability or the structure collapses.

After the structural modelling is completed, then the next step is to input the earthquake history data used. Then run a dynamic analysis of time history in stages with increasing earthquake intensity scale. In general, the analysis carried out in this study uses the addition of a scale factor of $0.5 ; 1$ and 2 . These additions are used to determine the limits of repeated load increases. The results of the analysis are displacements in the $\mathrm{x}$ and $\mathrm{y}$ directions. This displacement value is used to determine the value of the drift ratio which is useful in making the IDA curve.

\subsection{Fragility Curve}

Based on the results of structural analysis using the IDA method, IDA curves with various variations are obtained according to the number of earthquake records used as earthquake loads. The IDA curve can be further analyzed probabilistically by using the fragility function and expressed in the form of a fragility curve. In this study, the value of limit states follows the research of Kim and Shinozuka which is summarized in Pitiliakis [9]. The fragility curve shows the probability of damage to a structure when it receives an earthquake load with a certain intensity at its service limit. Based on the analytical method, the function is derived by Sadradin [10] through a log-normal distribution approach as follows:

$P=\phi\left(\frac{\ln (\mathrm{X})-\lambda)}{\beta_{\mathrm{RU}}}\right)$

where;

$\mathrm{P}=$ probability of structural damage,

$\Phi=$ The standard normal function,

$\beta R U=\quad$ The total uncertainty of the structure,

$\mathrm{x}=$ Ground motion parameter, PGA $(\mathrm{g})$,

$\lambda=$ average of $\ln (\mathrm{x})$.

\section{Result and discussion}

\subsection{Results of IDA curve analysis}

In making the IDA curve, an Intensity measure in the form of Peak Ground Acceleration (PGA) is needed for the $\mathrm{x}$-axis. Meanwhile, the damage measure used is the drift ratio for the y-axis. The analysis was stopped when the drift ratio was found to be more than $7-8 \%$, because it had crossed the largest limit state value. The results of the IDA curve analysis for earthquakes in the $\mathrm{x}$ and $\mathrm{y}$ directions can be seen in Figures 16 to 29.

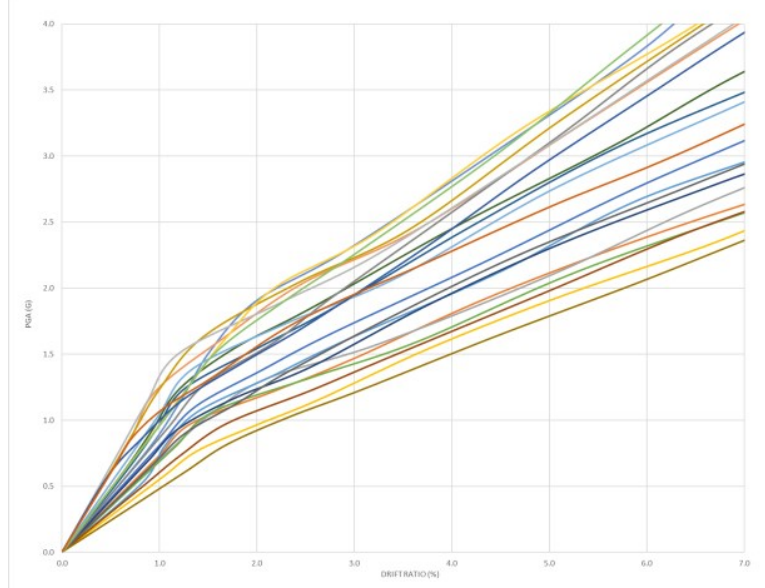

Fig 16. IDA Curve of TVE Lambung $x$-direction

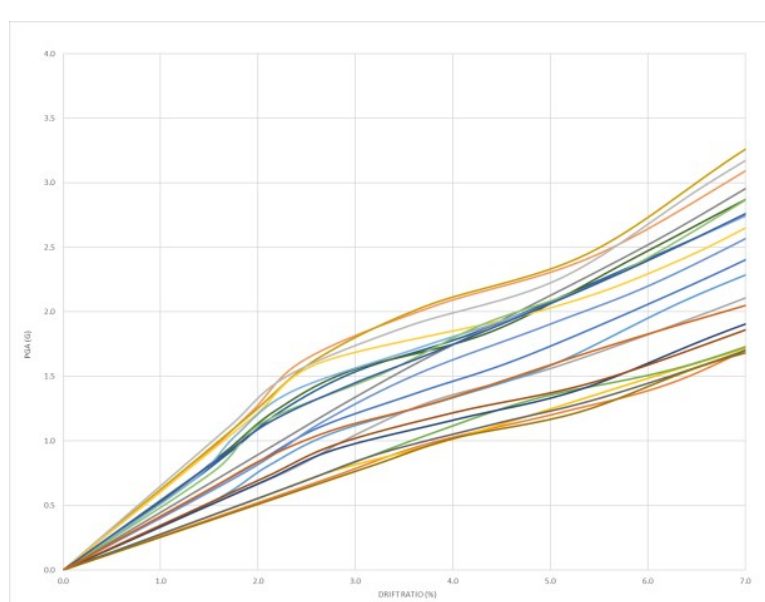

Fig 17. IDA Curve of TVE Lambung y-direction

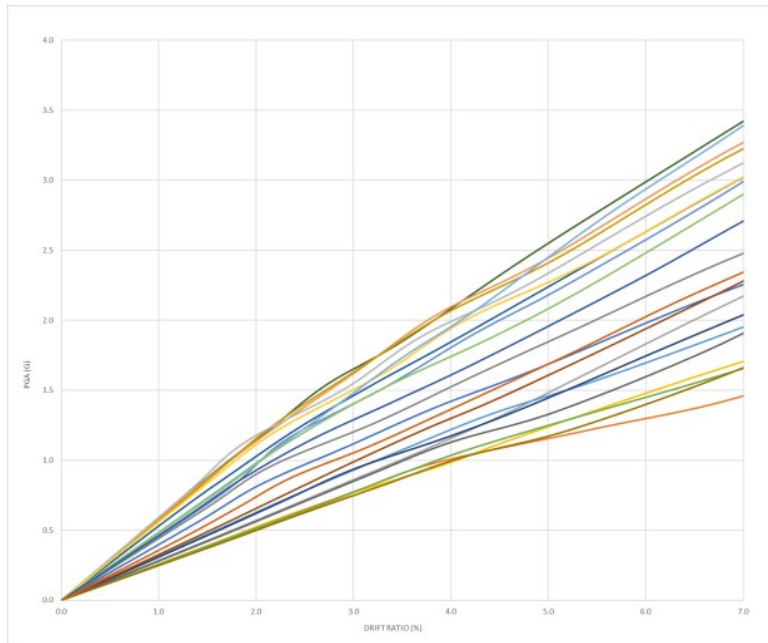

Fig 18. IDA Curve of TVE Alu Deah Teungoh x-direction 


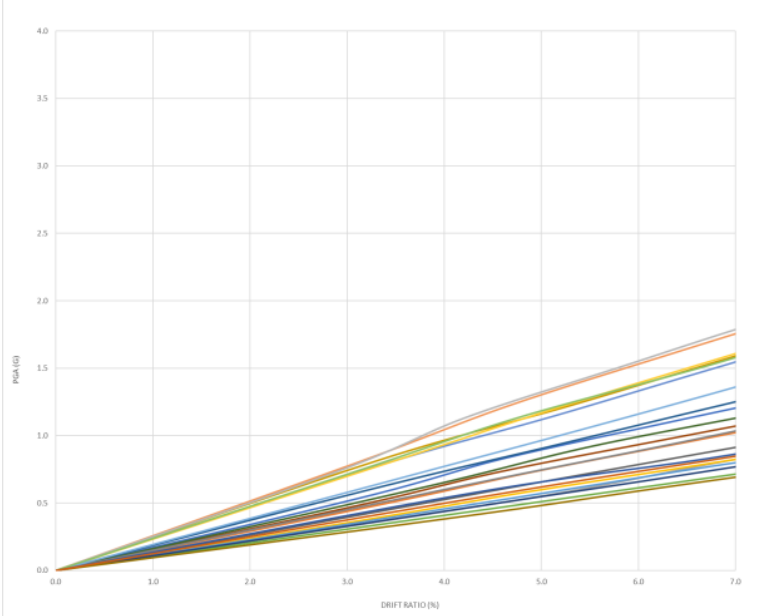

Fig 19. IDA Curve of TVE Alu Deah Teungoh y-direction

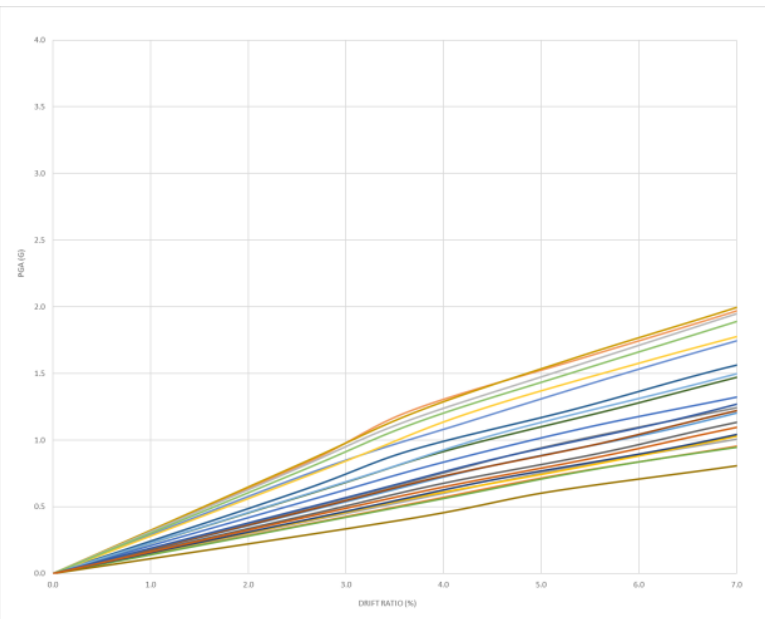

Fig 20. IDA Curve of TVE TDMRC x-direction

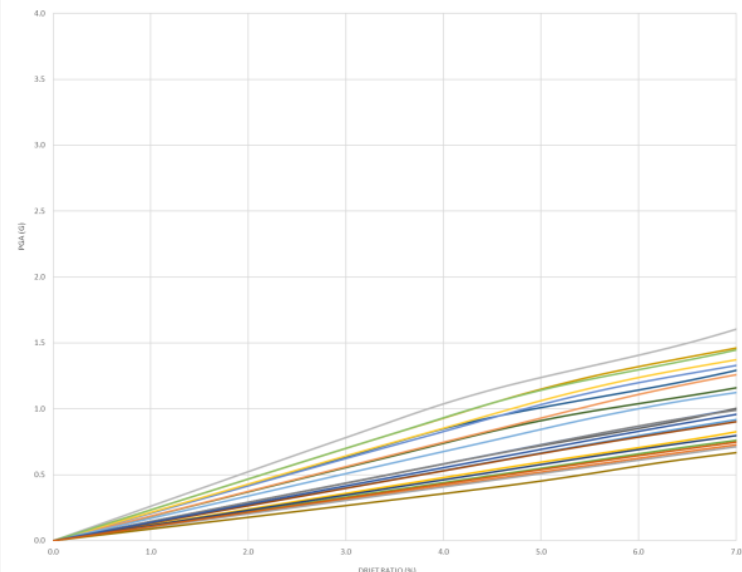

Fig 21. IDA Curve of TVE TDMRC y-direction

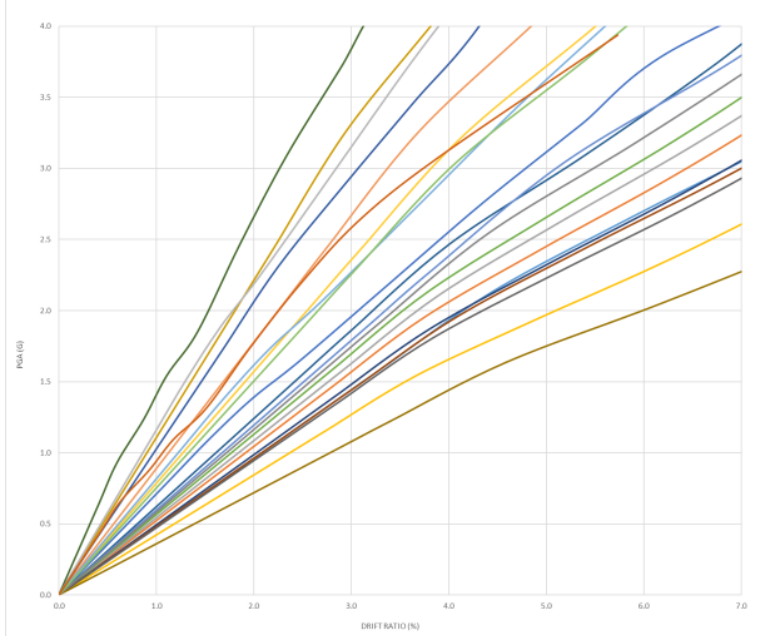

Fig 22. IDA Curve of SDN 48 Banda Aceh x-direction

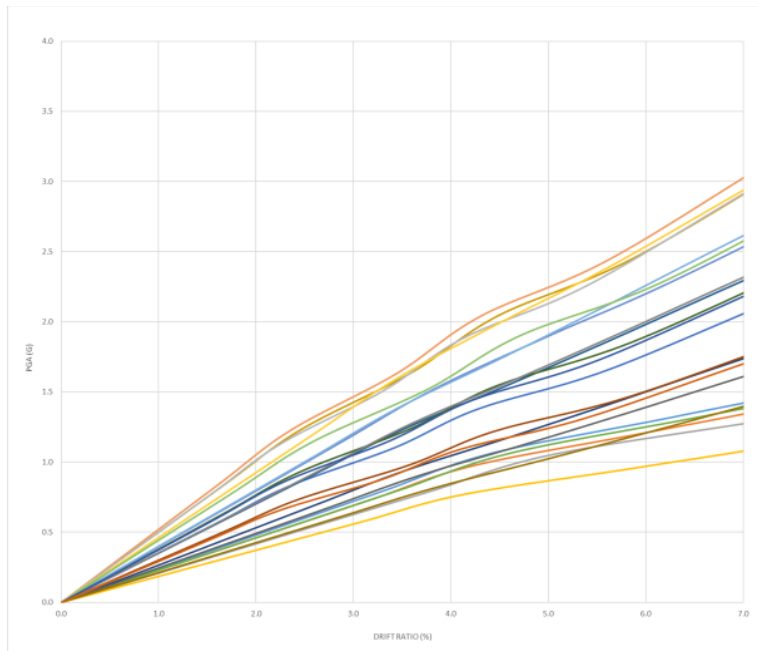

Fig 23. IDA Curve of SDN 48 Banda Aceh y-direction

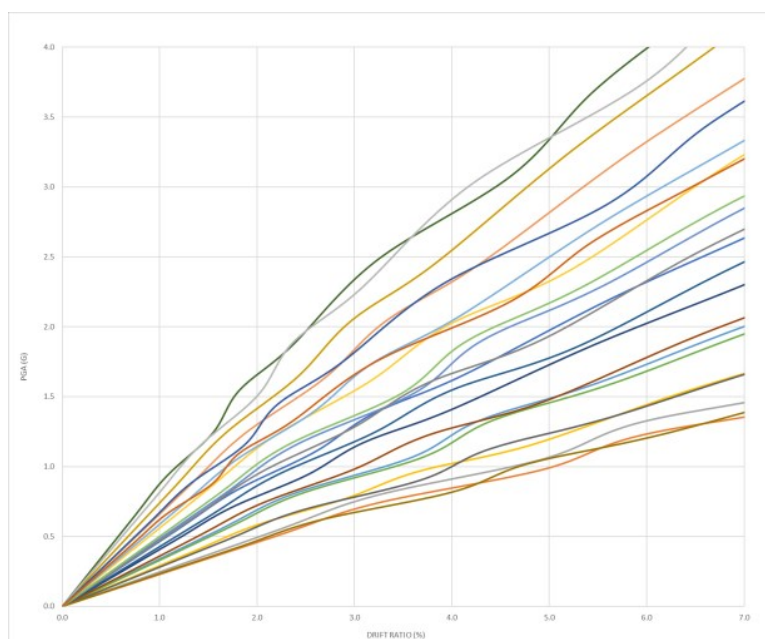

Fig 24. IDA Curve of SMPN 11 Banda Aceh x-direction 


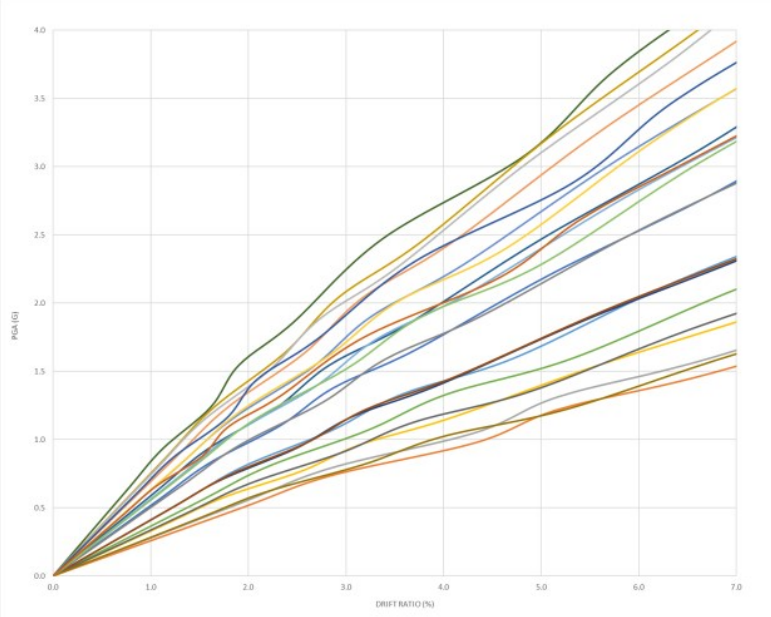

Fig 25. IDA Curve of SMPN 11 Banda Aceh y-direction

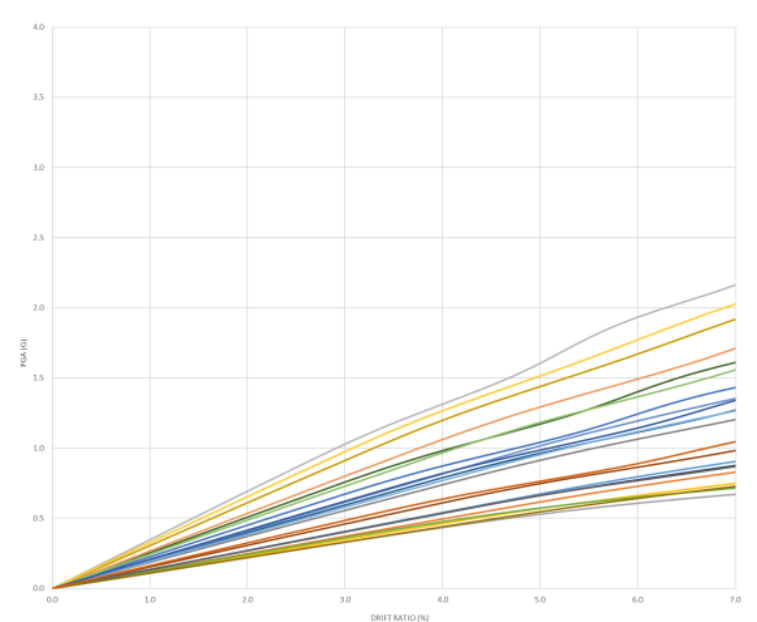

Fig 26. IDA Curve of Ulee Lheu Mosque x-direction

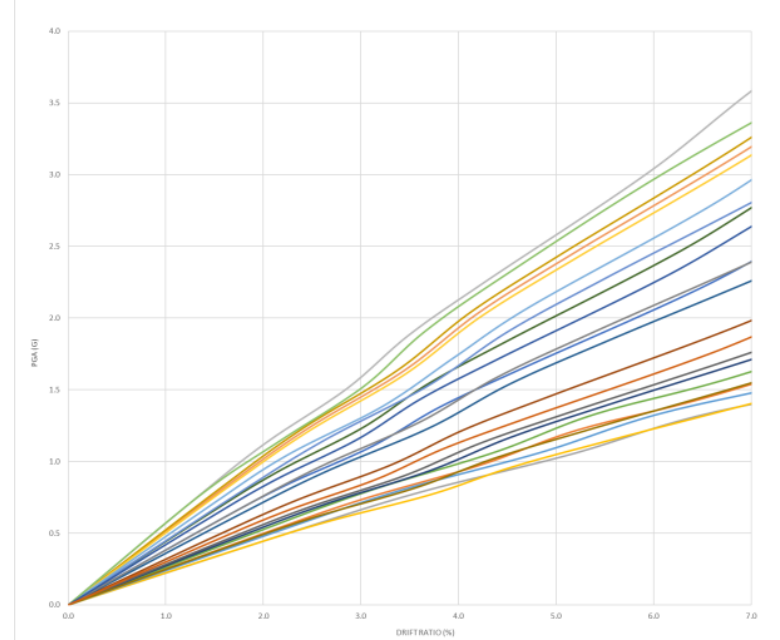

Fig 27. IDA Curve of Ulee Lheu Mosque y-direction

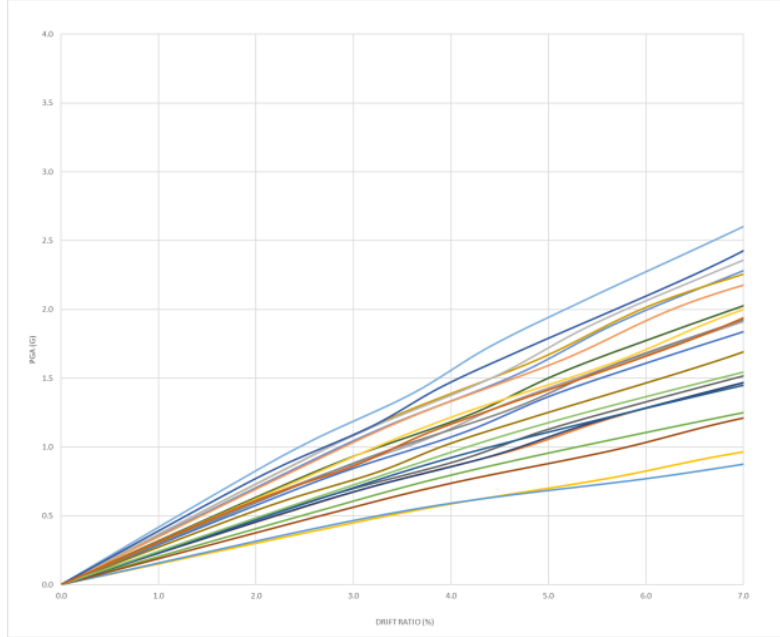

Fig 28. IDA Curve of Punge Mosque x-direction

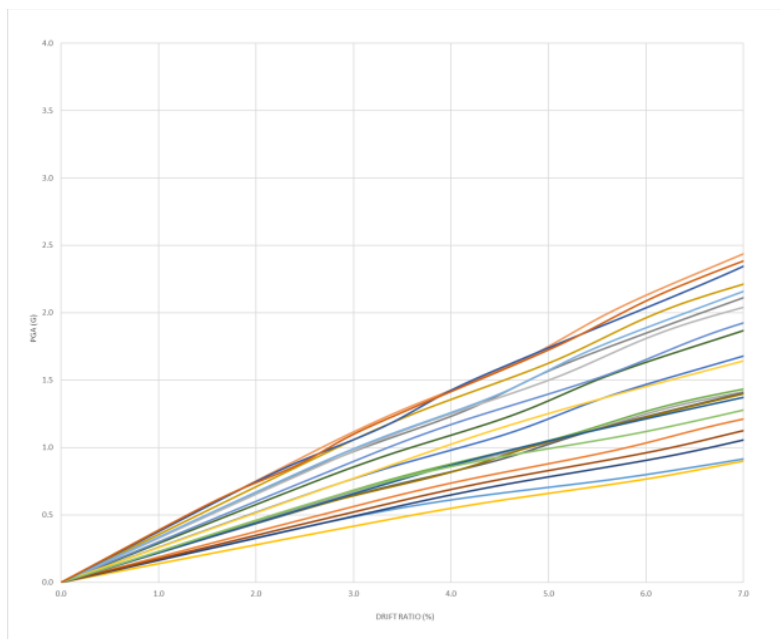

Fig 29. IDA Curve of Punge Mosque y-direction

\subsection{Results of fragility curve analysis}

The probability equation for the fragility curve is a function of the cumulative standard normal distribution. The variables needed are the ground motion parameter (PGA), the average of the ground motion parameters according to the limit state, and the total uncertainty. Based on these results, the complete fragility probability value is obtained at various limit states. The fragility probability value is plotted on the $\mathrm{y}$-axis (ordinate) along with the ground motion parameter on the $\mathrm{x}$-axis (abscissa). With this curve, the evaluation of the probability of existing building structures being damaged due to variations in the intensity of earthquake loads during their service life can be done quantitatively and rationally. The results of the fragility curves in the $\mathrm{x}$ and $\mathrm{y}$ directions can be seen in Figure 30 to 43 . 


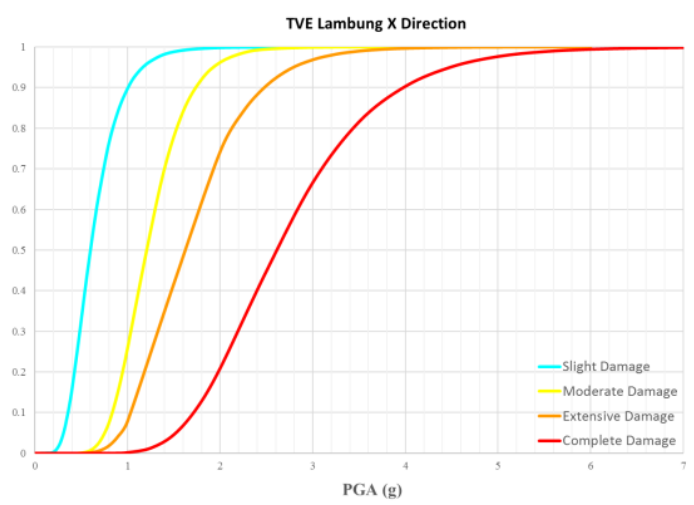

Fig 30 . Fragility Curve of TVE Lambung x-direction

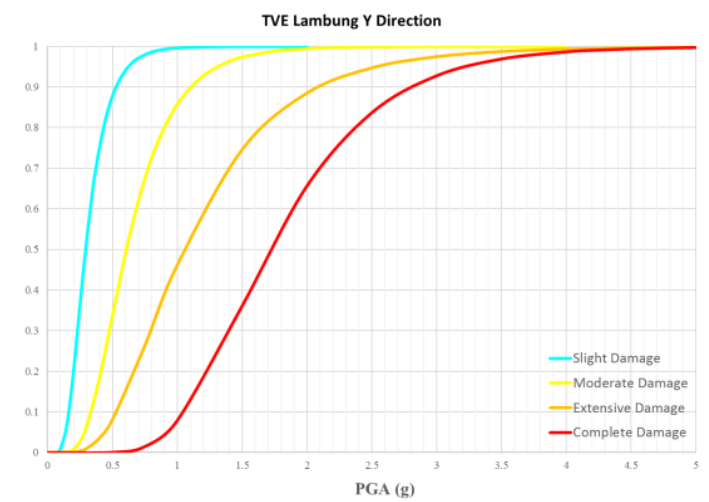

Fig 31. Fragility Curve of TVE Lambung y-direction

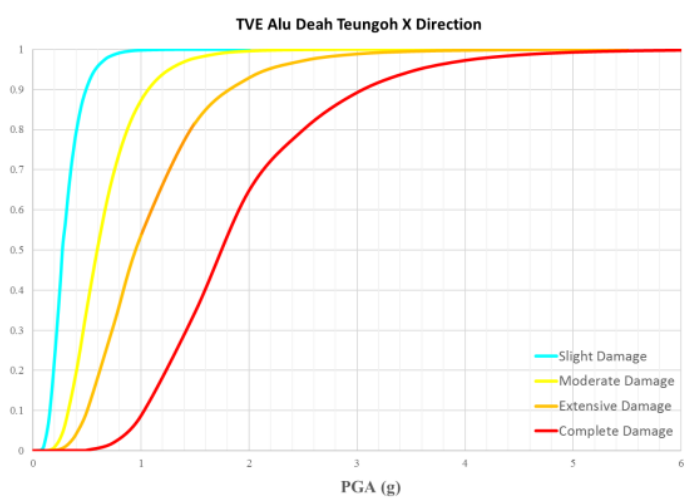

Fig 32. Fragility Curve of TVE Alu Deah Teungoh x-direction

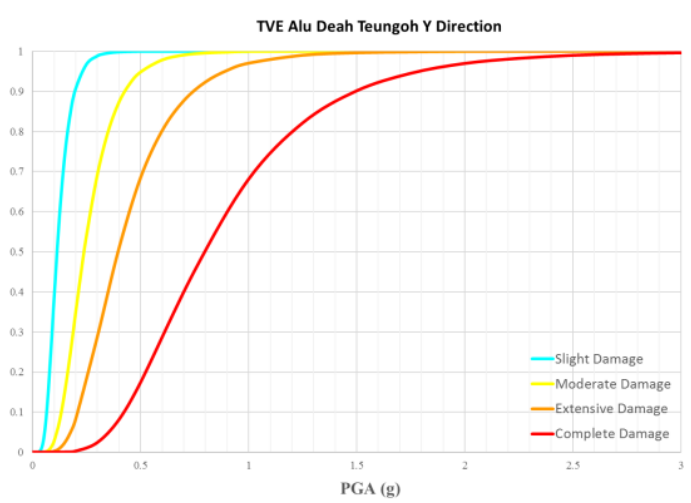

Fig 33. Fragility Curve of TVE Alu Deah Teungoh y-direction

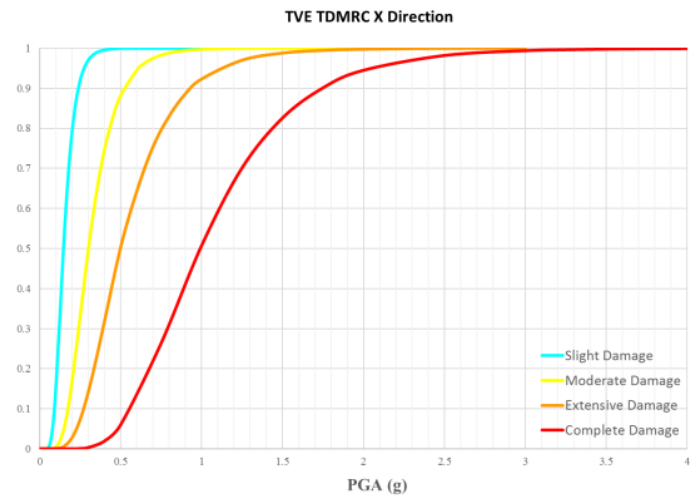

Fig 34. Fragility Curve of TVE TDMRC x-direction

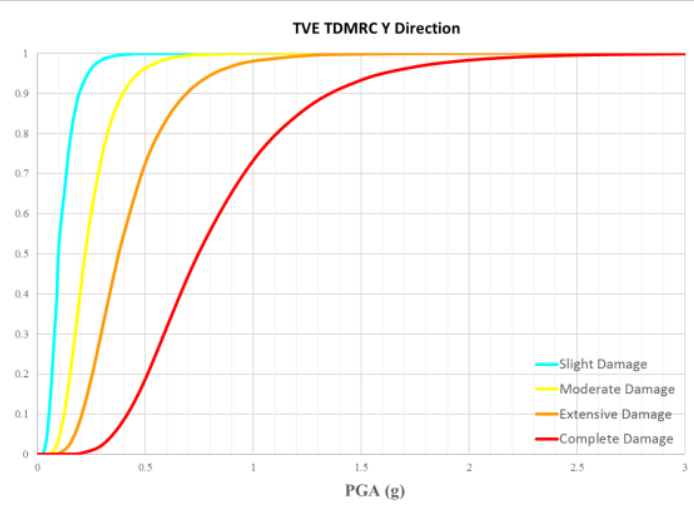

Fig 35. Fragility Curve of TVE TDMRC y-direction

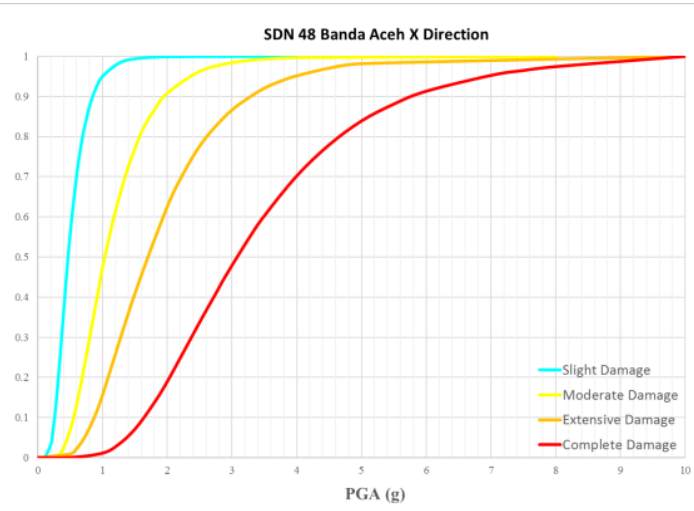

Fig 36. Fragility Curve of SDN 48 Banda Aceh x-direction

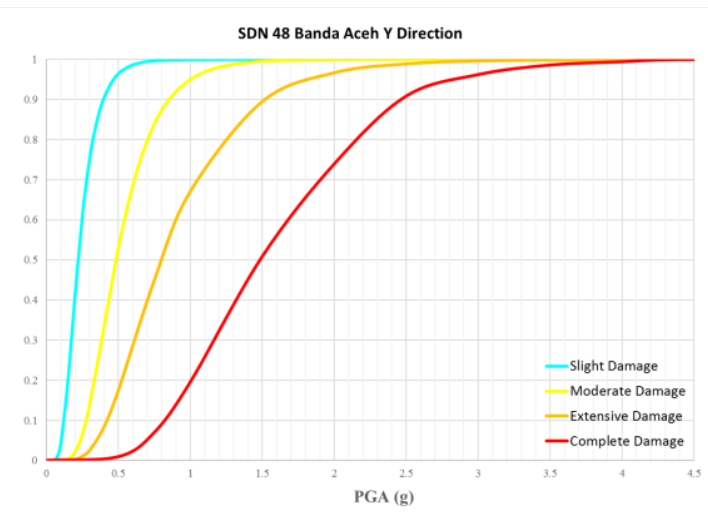

Fig 37. Fragility Curve of SDN 48 Banda Aceh y-direction 


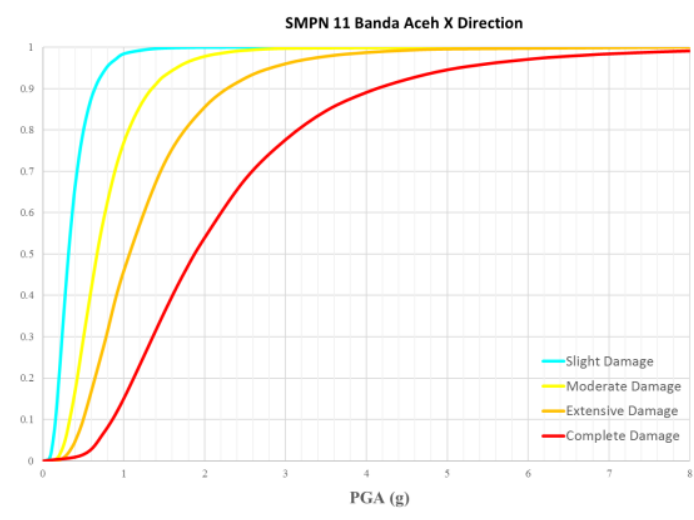

Fig 38. Fragility Curve of SMPN 11 Banda Aceh x-direction

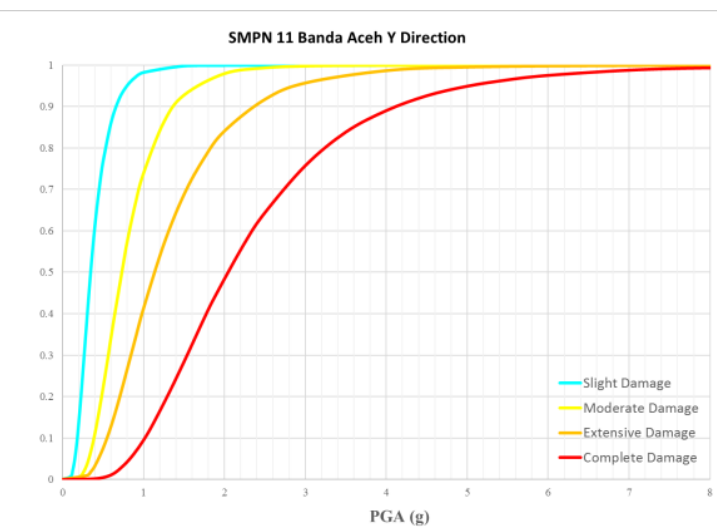

Fig 39. Fragility Curve of SMPN 11 Banda Aceh y-direction

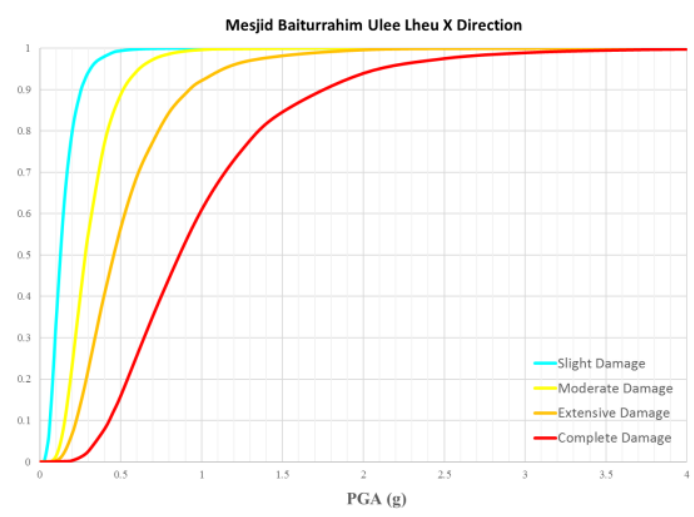

Fig 40. Fragility Curve of Ulee Lheu Mosque x-direction

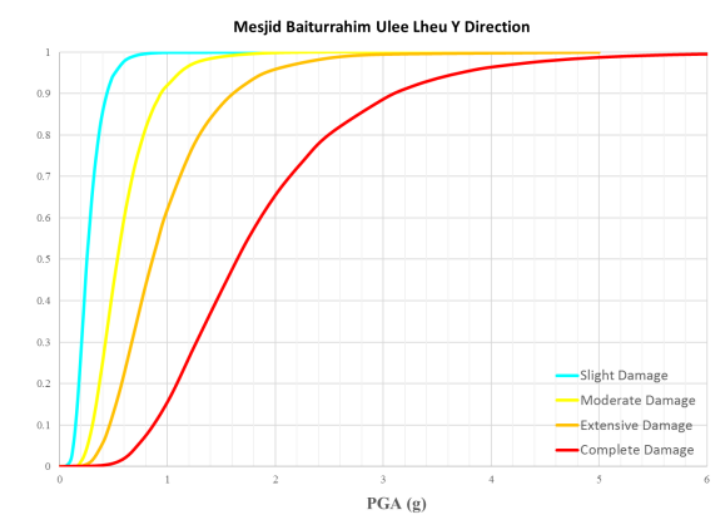

Fig 41. Fragility Curve of Ulee Lheue Mosque y-direction

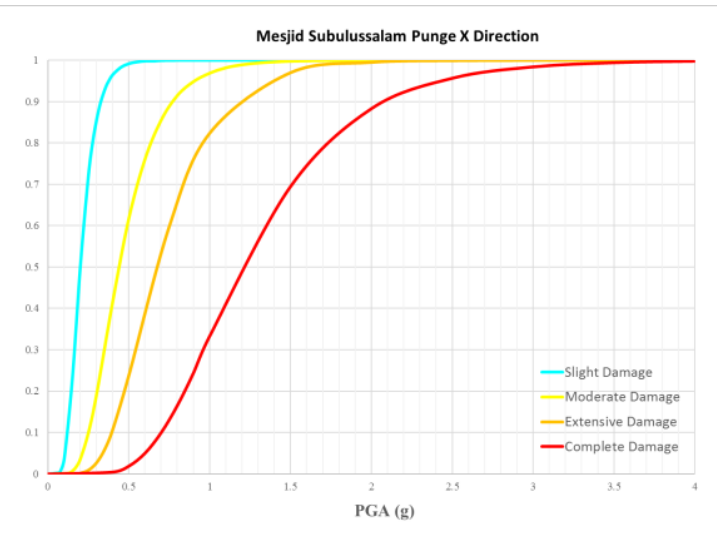

Fig 42. Fragility Curve of Punge Mosque $x$-direction

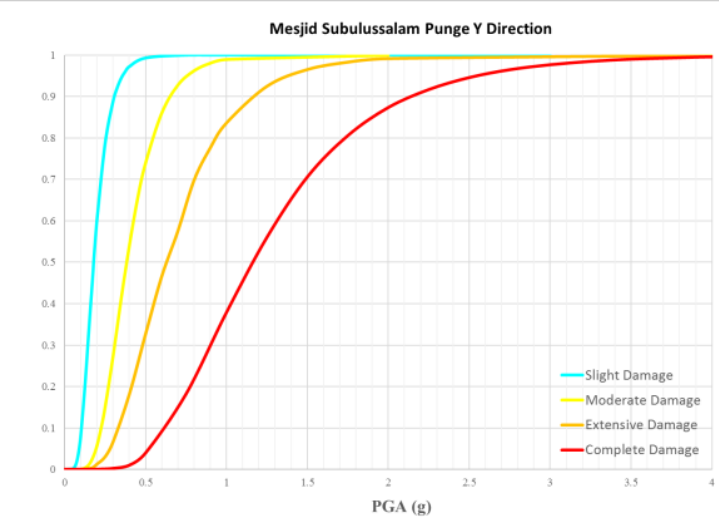

Fig 43. Fragility Curve of Punge Mosque y-direction

Based on the fragility curve formed, the building structure has a $100 \%$ probability of damage which can be seen in Table 2. From Table 2 below, it can be seen that the building structures for TVE, schools, and mosques have various probability values. This is influenced by the shape of the building, the number of floors of the building, the loading, and also the dimensions of the structure used.

The shape of the building is very influential for the probability of the $\mathrm{x}$ and $\mathrm{y}$ directions, we can see this in the Subulussalam Mosque which is almost symmetrical. The probability values in the $\mathrm{x}$ direction and $\mathrm{y}$ direction are the same and close to .. Unlike the case with the Baiturrahim Mosque which has an asymmetrical shape, the probability values for the $\mathrm{x}$ and $\mathrm{y}$ directions have different values. 
Tabel 2. Fragility curve Results for each building

\begin{tabular}{|c|c|c|c|c|c|}
\hline \multirow[b]{2}{*}{$\begin{array}{l}\text { Existing } \\
\text { Building }\end{array}$} & \multirow[b]{2}{*}{$\begin{array}{l}\text { Earthquake } \\
\text { Direction }\end{array}$} & \multicolumn{4}{|c|}{ Peak Ground Acceleration (g) } \\
\hline & & $\begin{array}{c}\text { Slight } \\
\text { Damage } \\
(100 \%)\end{array}$ & $\begin{array}{c}\text { Moderate } \\
\text { Damage } \\
(100 \%)\end{array}$ & $\begin{array}{l}\text { Extensive } \\
\text { Damage } \\
(100 \%)\end{array}$ & $\begin{array}{l}\text { Complete } \\
\text { Damage } \\
(100 \%)\end{array}$ \\
\hline \multirow{2}{*}{ TVE Lambung } & $\mathrm{x}$ & 2.1 & 2.7 & 4.5 & 7.0 \\
\hline & $\mathrm{y}$ & 1.3 & 2.6 & 4.4 & 5.0 \\
\hline \multirow{2}{*}{$\begin{array}{l}\text { TVE Alu Deah } \\
\text { Teungoh }\end{array}$} & $\mathrm{x}$ & 1.1 & 2.3 & 4.0 & 6.0 \\
\hline & $\mathrm{y}$ & 0.4 & 1.0 & 1.8 & 3.0 \\
\hline \multirow{2}{*}{ TVE TDMRC } & $\mathrm{x}$ & 0.4 & 1.1 & 2.1 & 4.0 \\
\hline & $\mathrm{y}$ & 0.5 & 0.8 & 1.6 & 3.2 \\
\hline \multirow{2}{*}{ SDN 48 Banda Aceh } & $\mathrm{x}$ & 1.9 & 3.8 & 7.6 & 10 \\
\hline & $\mathrm{y}$ & 0.9 & 1.7 & 3.2 & 4.2 \\
\hline \multirow{2}{*}{$\begin{array}{l}\text { SMPN } 11 \text { Banda } \\
\text { Aceh }\end{array}$} & $\mathrm{x}$ & 2.0 & 3 & 4.8 & 8.0 \\
\hline & $\mathrm{y}$ & 1.6 & 2.6 & 4.7 & 8.0 \\
\hline \multirow{2}{*}{$\begin{array}{l}\text { Baiturrahim Ulee } \\
\text { Lheu Mosque }\end{array}$} & $\mathrm{x}$ & 0.6 & 1.0 & 2.1 & 3.4 \\
\hline & $\mathrm{y}$ & 0.9 & 1.8 & 3.2 & 5.7 \\
\hline \multirow{2}{*}{$\begin{array}{l}\text { Subulussalam Punge } \\
\text { Mosque }\end{array}$} & $\mathrm{x}$ & 0.7 & 1.4 & 2.2 & 3.7 \\
\hline & $\mathrm{y}$ & 0.7 & 1.4 & 2.3 & 3.8 \\
\hline
\end{tabular}

\section{Conclusion}

The results of the fragility curve analysis show that the building structure is more susceptible to the y direction than the $\mathrm{x}$ direction. The vulnerability values of TVE Lambung, TVE Alu Deah Teungoh, TVE TDRMC, SDN 48, SMPN 11, Mesjid Ulee Lheu, and Mesjid Punge each have a probability sequentially, namely $100 \%$ slight damage in earthquakes with a PGA of 1,3 ; $0.4 ; 0.5 ; 0.9 ; 1.6 ; 0.9 ; 0.7$, moderate damage at PGA 2.6; $1 ; 0.8 ; 1.7 ; 2.6 ; 1.8 ; 1.4$, extensive damage on PGA 4.4; $1.8 ; 1.6 ; 3.2 ; 4.7 ; 3.2 ; 2,3$, and complete damage during an earthquake with a PGA of $5 ; 3 ; 3.2 ; 4.2 ; 8 ; 5.7 ; 3.8$. These results indicate that it is necessary to carry out periodic maintenance of the existing building in order to become a strong building and ready for use if a largescale earthquake occurs.

For the existing building structure, it is recommended that structural mitigation efforts related to improving the condition and strengthening of the building structure, especially in the column section, are recommended. One of the efforts to strengthen the flexural column is done by adding reinforcement method. In addition, other column retrofitting efforts can be in the form of column jacketing. Jacketing material in the form of a sheath that can protect the concrete against damage. This sheath material can be metal, steel, rubber, concrete, composites. This method is commonly used for column reinforcement repair.
Acknowledgement. This research was conducted independently without external funding. The authors are grateful to Mr. Rifqi Irvansyah for the assistance provided in the experimental work.

\section{References}

1. National Institute of Building Science (NIBS). 2002. HAZUS (Hazard US), (1999): Earthquake Loss Estimation. National Institute of Building Sciences, NIBS: Washington D.C.

2. Irvansyah, Rifqi, 2019. Evaluasi Kinerja Seismik pada Tipikal Bangunan Sekolah di Kota Banda Aceh dengan Pengembangan Kurva Kerapuhan Berbasis Incremental Dynamic Analysis. Universitas Syiah Kuala, Indonesia.

3. Aulia, Fajarul, 2019. Evaluasi Kinerja Seismik pada Tipikal Bangunan Sekolah di Kota Banda Aceh dengan Pengembangan Kurva Kerapuhan Berbasis Pushover Analysis.. Universitas Syiah Kuala, Indonesia.

4. Federal Emergency Management Agency, 2001. Earthquake Loss Estimation Methodology: Hazus MH 2.1. Department of Homeland Security FEMA Mitigation Division: Washington D.C.

5. Pacific Earthquake Engineering Research Center. Berkeley, University of California, USA. http://peer.berkeley.edu/peer_ground_motion_data base. Accesed on 25 Agustus 2020.

6. Badan Meteorologi Klimatologi dan Geofisika (BMKG) Data Base. Accesed on 27 September 2020. 
7. Badan Standarisasi Nasional, 2019. Standar Nasional Indonesia 1726-2019: Tata Cara Perencanaan Ketahanan Gempa untuk Struktur Bangunan Gedung dan Non Gedung. Badan Standarisasi Nasional, Jakarta.

8. Tiwari, V. dan Kasnale, A., 2017. Incremental Dynamic Analysis of RC Frames. IRJET, 4(6): 697700.

9. Pitilakis, K., et al, 2005. SYNER-G : Typology Definiton and Fragility Functions for Physical Elements at Seismic Risk. Springer: Netherlands.

10. Sadraddin, H., 2015. Fragility Assesment of HighRise Reinforced Concrete Buildings. Tesis, Civil and Construction Engineering Western Michigan University, Kalamazoo. 